\title{
TCOM \\ Climate change skeptics teach climate literacy? A critical discourse analysis of children's books
}

\section{Nicole M. Colston and Julie Thomas}

Abstract

Keywords

DOI

Context
This critical discourse analysis examined climate change denial books intended for children and parents as examples of pseudo-educational materials reproduced within the conservative echo chamber in the United States. Guided by previous excavations in climate change denial discourses, we identified different types of skepticism, policy frames, contested scientific knowledge, and uncertainty appeals. Findings identify the ways these children's books introduced a logic of non-problematicity about environmental problems bolstered by contradictory forms of climate change skepticism and polarizing social-conflict frames. These results pose pedagogical dilemmas for educators, environmental advocates, and communication experts interested in advancing understanding and action in the face of rapid climate change.

Environmental communication; Science and media; Science education

https://doi.org/10.22323/2.18040202

Submitted: 16th July 2018

Accepted: 13th May 2019

Published: 8th July 2019

In early 2019, students from across the globe mobilized via social media to organize "school strikes" to protest governments' failure to respond to a rapidly changing global climate [Youth climate strike, 2019]. With youth clearly positioned at the forefront of the global climate change movement, environmental education and climate change communication scholars are increasingly interested in the role of new media platforms to mobilize of youth citizenship and climate actions on local and global scales, including strategies like speculative fiction [Rousell, Cutter-Mackenzie and Foster, 2017] and digital story-telling [Truong-White and McLean, 2015]. However, in addition to mediated pedagogies, it is also important for youth to understand the science of climate change. Effective climate change communication requires an understanding of the complex working of the climate system and the influence of human-caused atmospheric warming on this system as well as the resulting impacts on extreme weather; food and water security;

biodiversity and ecosystem health; and human health and security. 
A vast number of resources for climate change education in schools have emerged in the last 10-15 years in the United States, seemingly in reaction to widespread climate change denial in the public sphere. While a great deal of research examines the impact of curriculum and programs on youth understanding of the science of climate and global warming [Monroe et al., 2017], there are no studies assessing the influence of widespread climate change denial on youths' attitudes and understanding about climate change. In this article, we introduce the problem of climate change denial media and its influence on school science in the United States. Our research explores the phenomena of climate change denial in literature books aimed at children. Methods of critical discourse analysis reveal the rhetoric and translation of climate change denial for youth audiences and highlight the way in which linguistic choices might interact to (re)produce the social relations, ideologies, and power dynamics sustained by organized climate change denial campaigns.

\section{Climate change denial in the media}

In an exposé of the organized climate change denial machine, Dunlap and McCright [2011] identified the major actors responsible for the widespread dissemination of climate change denial in the United States: the fossil fuel industry, corporate America, conservative think tanks and foundations, environmental front groups (acting on behalf of the former), and other astroturf organizations (disguised as grassroots movements). The resulting media, politicians, and blogs are indicative of coordinated efforts to wield enormous political and economic power against climate change policy making. Often associated with conservative political movements [Dunlap and McCright, 2011], these organized climate change denial campaigns are a driving mechanism for mobilizing a logic of non-problematicity that challenges the social construction of climate change as a problem [Freudenburg, 2000]. The campaigns generate public contestation about the reality, causes, impacts, and solutions to problems associated with global climate change [McCright and Dunlap, 2000; Rahmstorf, 2004] and are sustained by the social construction of a polarized camp of climate change skeptics, denialists, and contrarians acting in resistance to climate change believers and alarmists [Sharman and Howarth, 2017].

It is widely documented that climate change denial campaigns in the United States generate manufactured controversy, delegitimize scientific consensus about global warming, and stifle environmental governance [Ceccarelli, 2011b; McCright and Dunlap, 2000]. There is a large body of research analyzing media coverage of climate change, including many focused on the social construction and dissemination of climate change denial and skepticism in news media [Antilla, 2005; Boykoff and Boykoff, 2004]. More than just texts, media discourses present models of the world that suggest a cast of characters, motivations, actions, and social values. Representations of climate change in the media are likely to influence individuals understanding of the risks and sense of responsibility to act [Carvalho, 2010].

Numerous case studies of climate change denial texts point to the rhetorical currency of politicizing, deconstructing, and delegitimizing scientific consensus about global warming [Ceccarelli, 2011a; Oreskes and Conway, 2010]. Climate 
change denial discourses often cite questionable "scientific" counterevidence about alternative causes of global warming, deploy ad hominem attacks, and foster polarizing frames designed to question the legitimacy of environmental problems [Weart, 2011]. Additional documented examples of such scientization (or misrepresentation of scientific facts to support a particular political agenda) include using scientific information to create misinformation campaigns; reporting data from faulty scientific models; deploying absurd alternate causality arguments; misusing and de-contextualizing scientific evidence; and employing stealth budgeting to sustain structural barriers to new research [Peterson, Connolley and Fleck, 2008, p. 1333].

The effect of these campaigns generates what social and political scientists have described as an 'echo chamber' that amplifies and entrenches ideologically driven ideas (the 'echo') sustained within enclosed networks of social groups (the 'chamber') [Farrell, 2015]. In the case of climate change denial campaigns, conservative echo chambers composed of media, blogs, and politicians amplify manufactured uncertainty about anthropogenic climate change [Dunlap and McCright, 2011]. Recent Dugan [2015] polls confirm a large partisan gap in global warming opinions, with conservative Republicans often rejecting the possibility of global warming and asserting changes to the environment are due to natural causes. A Pew Institute (2017) poll confirmed this trend and found Republicans were considerably more skeptical of climate scientists' information, understanding, and research findings on climate matters.

\section{Climate change denial in schools}

Perhaps indicative of the effects of the conservative echo chamber, public debate about the certainty of climate change has now extended to contestations about how to teach science in public school classrooms in the United States [Reardon, 2011]. In recent years, anti-science legislation (passed in several states) denies scientific consensus on global warming based on academic freedom; often coupling climate change with other controversial topics (i.e. evolution) in science classrooms [Colston and Vadjunec, 2015; National Center for Science Education, 2012]. In other cases, there has been political resistance to the state-level adoption of the Next Generation Science Standards (NGSS), which unequivocally link human activities to climate change [Colston and Ivey, 2015]. Teachers across the nation, who are engaged in climate change education, reported increasing experiences with pushback about teaching climate change from school administrators, parents, and students [Johnson, 2011].

Shocking examples of climate change denial media have also emerged in educational spheres, including The Skeptics Handbook [Nova, 2009] that was distributed to over 14,000 schools boards in the United States [Reardon, 2011]. This handbook advised school leaders to ignore the evidence of climate change and to focus on four key issues emphasizing scientific uncertainty: (a) the greenhouse signature is missing, (b) ice cores do not support carbon as a driver of climate change, (c) temperatures are not rising, and (d) carbon dioxide is doing almost all the warming it can do). Cook [2009] quickly followed with A Scientific Guide to the 'Skeptics Handbook' to highlight the scientific basis of human-induced global warming and specify the logical fallacies within the first handbook. In 2017, 
the Heartland Institute sent another book and instructional DVD entitled Why Scientists Disagree about Global Warming to 200,000 K-12 science teachers in the United State [Worth, 2017].

The purpose of this research was to explore the translation of climate change denial in similar pseudo-educational materials, specifically children's books. This research asked, how are climate change denial discourses reproduced in children's books? These books are conceptualized here as a unique form of media designed to counter the dissemination of a growing body of climate change education curriculum and media [Cooper, 2011]. While media literacy for children is considered a key strategy toward improving public attitudes about climate change science, there is very little research on the nature or impact of climate change denial discourses found in children's media. Answers to this research question will be practically significant to science educators organizing instruction in the face of widespread misconceptions and political pushback [Colston and Vadjunec, 2015; Cook and Lewandowsky, 2011; McBean and Hengeveld, 2000]. Environmental educators and climate change communicators interested in activating youth interest and action will benefit from a better understanding of the rhetorical strategies employed in educational and youth-focused media.

Discourse analysis, particularly research in the framing of climate change and global environmental problems, is an increasingly embraced methodology across many disciplines [Buttel, 2000; Cox, 2013]. Critical discourse analysis (CDA) is a theoretical and methodological approach, rooted in political ecology, that regards language as social practice and investigates the social contexts within which symbolic forms are deployed and index power [Wodak and Meyer, 2015]. For example, political ecologists point to the ways the global climate change governance has institutionalized practices that construct science and policy-makers as the main protagonists in climate change narratives [Doyle, 2011; Reitan and Gibson, 2012; Wainwright and Mann, 2013]. This results in dominant narratives of ecological modernization that tend to focus public climate change discourses on questions about who pays the costs of policy actions, whether we should have decentralized or centralized systems, and whether the costs of action outweigh the benefits [Bäckstrand and Lövbrand, 2007]. Often associated with climate change denial campaigns, a dominant counter-narrative to ecological modernization includes the deployment (and challenging) of scientific consensus behind calls for climate change action.

As an analytical model, CDA has been used to better understand the science learning discourses found in textbooks and curriculum documents. Viewed as texts-in-context, CDA includes a careful examination of the verbal and visual language within educational texts supporting the development of science knowledge [Knain, 2015; Lemke, 1993]. CDA lends itself easily to an examination of how linguistic choices might interact to (re)produce the social relations, ideologies, and power dynamics sustained by organized climate change denial campaigns [Hansen and Machin, 2008]. Indeed, the constitutive power of the conservative echo chamber seemingly lies in the ability to limit alternative discourses and relatedly the knowledge and beliefs needed to challenge climate change skepticism. 
For this article, we focused on a small set of children's books authored by self-identified climate change skeptics and conceptualized here as a unique form of media designed to counter the dissemination of a growing body of climate science literature and climate education policymaking [Cooper, 2011]. In their review of publications circulated on the websites of prominent conservative think tanks, McCright and Dunlap [2000] identified three children's books authored by self-identified climate change skeptics. In effort to identify a purposive sample of similar books, we completed a general search for children's book on Amazon.com using the terms global warming and climate change. We categorized these books $(n=12)$ using a typology of global climate change portrayals ranging from adherent to hesitant to dismissive [Meehan, Levy and Collet-Gildard, 2018].

In this process, we identified a number of books appropriate for use in a science classroom that accurately attributed climate change to human causes and discussed the science behind climate change. Some notable examples include How We Know What We Know About Our Changing Climate [Cherry and Braasch, 2008] and The Wizard Who Save the World [Bennett and Collier-Morales, 2011]. Other books were limited in their use of science terms or in their presentation of the impacts of climate change, for example Winston of Churchill: One Bear's Battle Against Global Warming [Okimoto and Trammell, 2013]. A few were hesitant to attribute human causes to climate change, for example America Debates Global Warming: Crisis or Myth? [Robinson, 2008]. However, we were not able to find any additional of examples of children's books that clearly dismissed the theory of global warming.

The three books identified by in the McCright and Dunlap [2000] study and analysed in this study are clearly dismissive of the causes and impacts of climate change. The authors' of all three selected books are self-reported climate change skeptics and the titles of these books have clearly dismissive tones: (1) Deb and Seby's Real Deal on Global Warming: The 'Other-side' of the Man-made Global Warming Issues [Schmidt, 2008], (2) The Sky's not Falling: Why it's OK to Chill about Global Warming [Fretwell, 2007], and (3) We're not scared anymore Mr. Gore (A Climate Change Story for Little Skeptics) [Hendrickx, 2008a]. In sum, these titles suggest that readers view climate change as a non-problem (i.e., the sky is not falling, we can all chill out, no need to be scared, no crisis here).

The following summaries aim to contextualize the origins and themes of each book, including the main ideas, authors' credentials, and publishing information. First, We're Not Scared Anymore Mr. Gore (A Climate Change Story for Little Skeptics) is a self-published book (Little Skeptics Press) by author Marc Hendrickx [2008a]. The author's biography lists a Bachelor of Science degree from Latrobe University in Australia and work experience as a geologist. The narrative storyline of We're Not Scared includes a fictional classroom visit from Al Gore where the students cite contrarian scientific research, indict popular climate models (i.e. hockey stick graph for global warming), and evoke personal experience to disprove scientists' predictions. Crude computer illustrations and confrontational rhetoric pit teacher and students against $\mathrm{Al}$ Gore's presentations of science inside the school. Meanwhile, children play outside (visible through a classroom window) in an environment of increasing glacial snow accumulation as the book progresses. An author-narrated version of this storybook is available on YouTube ("We are not scared anymore Al Gore", [2008b]). 
Deb E Seby's Real Deal on Global Warming, a self-published book (Author House) by Al Sonja Schmidt (2008), is a self-admitted response to the images of environmental destruction bombarding children in the classroom. The author has appeared on television concerning fear appeals and social norms that influence kid's global warming beliefs (Al Sonja Schmidt on Fox Business, [2008]). Real Deal appeals to a teen audience via hip cartoons and informal slang. Framing global warming as manufactured controversy by environmentalists, the teen narrators of the Real Deal reinforce political and social controversy over the existence of human-caused global warming and warn about the dangers of environmental legislation. In a companion blog website by Deb and Seby, young readers can check out the facts for themselves.

The Sky's Not Falling: Why It's OK to Chill about Global Warming is written and self-published by Holly Fretwell [2007], a Research Fellow at the Property and Environment Research Center (PERC). Informed by a BA in Political Science and an MS in Resource Economics from Montana State University, Fretwell writes articles with themes in free market environmentalism and describes environmental education as the science of fear [Fretwell, 2009]. Playing on the story of Chicken Little [Nathan, 1951], Sky's Not Falling illustrates the facets of an ever-changing planet and challenges the notion of human-caused global warming. The book includes a section calling on parents to make up their own mind and encourage critical thinking in their children. Drawing on common Earth science content, the book criticizes the effectiveness of environmental policy making and teaches children that temperature change is natural (i.e. weather change is not necessarily bad or violent). Focused on free-market economics, the book concludes by encouraging students to become enviroprenuers (entrepreneurs who work for the environment) rather than environmentalists who "panic about environmental problems" [Fretwell, 2007, p. 76].

\section{Coding and instrumentation}

For this study, we developed a procedure for categorical coding and comparative analyses aimed at assessing the interplay between climate change skepticism and the logic of non-problematicity [Creswell and Plano Clark, 2007]. Existing literature on the rhetoric of climate change skepticism guided a theoretical approach to categorical code development. We modified categories of rhetorical strategies from previous excavations in climate change denial discourses (see Figure 1), including: (a) climate change skepticism arguments [Dunlap and McCright, 2010; Rahmstorf, 2004], (b) frames for climate change policy making [Nisbet, 2009], (c) areas of contested scientific knowledge [McCaffrey and Buhr, 2008], and (d) appeals for managing the uncertainty of climate change [Norton, Sias and Brown, 2011]. A comparative coding process during both the protocol development and analysis increased the overall study reliability. Importantly, this process of reflective, double-coding by the authors focused on tagging selected book passages for examples of each rhetorical strategy and then reviewing them together. Thus, our approach to coding involved incidental coding (or example-based) rather than numeric scoring.

First, each book was reviewed for the presence of four common climate change skepticism arguments (trend, impact, policy, and attribution skepticism) identified as characterizing the discourse of contemporary climate change denial campaigns 


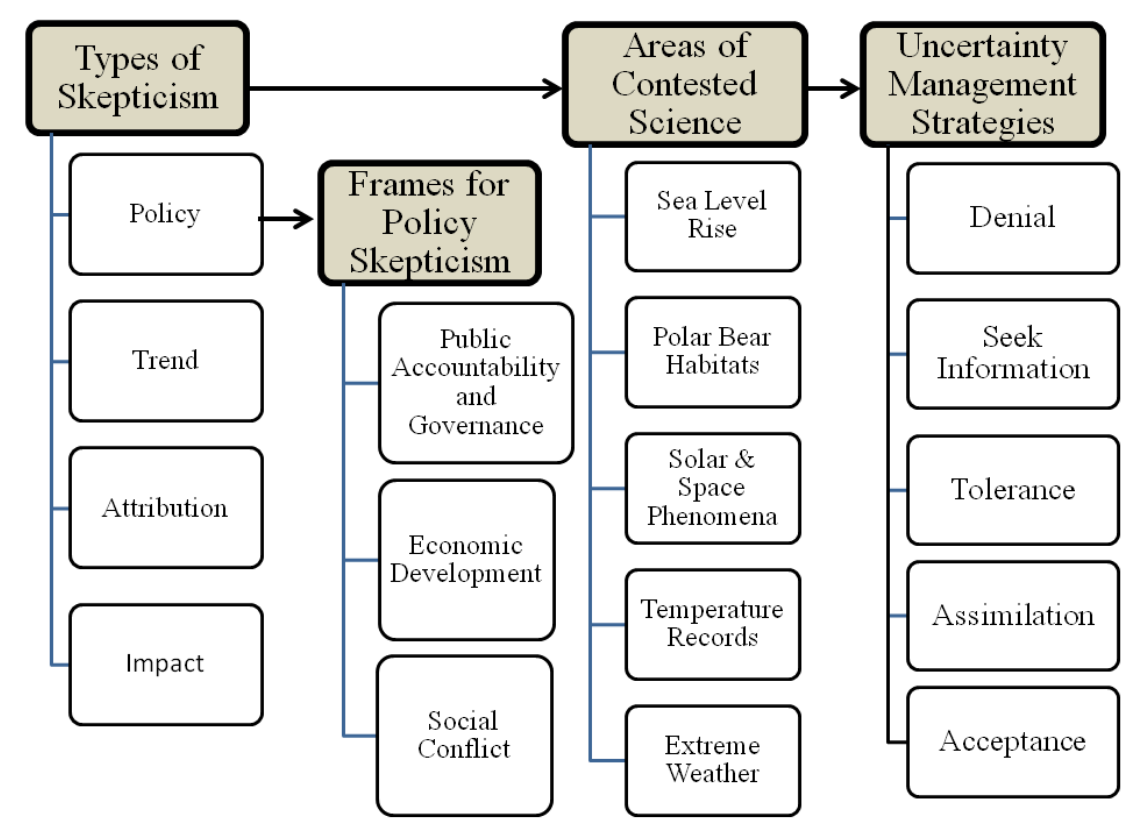

Figure 1. Four coding categories and their constructs.

targeted at adults [Dunlap and McCright, 2010; Rahmstorf, 2004]. Coding incidents of these common skeptical arguments for adults allowed us to note parallel messages in media focused on children. We identified and coded claims about climate change which raised questions about: what is happening (trend), what will happen (impact), what influence we do have (attribution) and what we can or should do about it (policy).

Next, conceptualizing the global warming controversy in the United States as a framing contest [Benford and Snow, 2000], we explored the deployment of policy skepticism frames. Content analysis focused on extracting and open coding specific framing devices (value appeals, latent meaning, catch phrases, images, and pop culture references) that guide readers' understanding about the climate policy controversies.

We also identified areas of contested scientific knowledge to explore the rhetoric of scientific uncertainty about climate change found in each book. The protocol included capturing citations or indictments of scientific 'evidence' (e.g. referenced studies, statistics, and expert quotes), images of scientific charts and graphs, and/or representations of basic climate science and Earth science concepts [Glaser and Strauss, 1967].

Finally, we coded for suggested strategies for dealing with the uncertainty of science and climate change. Research by Norton, Sias and Brown [2011] guided an interpretative strategy for coding which proved useful for exploring how climate change denial books ask readers to cope with uncertainty about scientific consensus and the reality of climate change. For this study, we identified direct statements encouraging one of five common management strategies. These included seeking information, denial, tolerance/assimilation, acceptance, and imagined information seeking [Norton, Sias and Brown, 2011]. By definition, the logic of 
non-problematicity implies as a broad strategy of denying the problem of climate change; however, it was expected from pre-coding that the reviewed books would also deploy a range of both active and passive uncertainty management strategies.

\section{Results}

This section reports the synthesized results of the content analysis procedures. First, we provide examples of skeptical claims found in each book which engender uncertainty about what is happening (trend skepticism), what will happen (impact skepticism), what influence we have (attribution skepticism), and what we can or should do about it (policy skepticism). A synthesis of contested areas of scientific knowledge highlights strategies aimed at engendering or perpetuating common misconceptions about Earth systems, often via appeals to scientific authority. Turning to specific examples of policy skepticism, analyses revealed several prominent and blended frames (public accountability, environmental governance, and social conflict) aimed at promoting controversy about environmental policy making and challenging dominant discourses about ecological modernization. Finally, the results provide examples of uncertainty management appeals that activate a complicated notion of individual agency that stands in opposition to the norms of scientific consensus.

\section{Types of skepticism}

How do we know if global warming is happening? Trend skepticism questions the actual phenomena of climate change and rising temperatures. Within the analyzed books, this form of skepticism included appeals to scientific uncertainty and often positioned global warming consensus as a function of politicized science. Efforts to undermine both science and scientific consensus are demonstrated in the provided examples (Table 1) of scientists' inability to make accurate predictions or models, challenges to the meaning and value of scientific consensus, and characterizations of scientists as both self-interested and influenced by environmentalist politics.

Table 1. Examples of trend skepticism delegitimizing science and scientific consensus.

\begin{tabular}{|ll|}
\hline Children's Book & How can we know if global warming is happening? \\
\hline Sky's Not Falling & $\begin{array}{l}\text { "There are too many factors involved that even the smartest scient- } \\
\text { ists are uncertain about." (p. 10) } \\
\text { "Think of the times the weather forecaster on TV told you it would } \\
\text { be sunny for your soccer game but it rained instead." (p. 7) }\end{array}$ \\
\hline We're Not Scared & "Computer models have not been able to predict temperature \\
& changes over the last 20 years. Why would anyone trust them to \\
& predict climate 100 years in the future?" (p. 6) \\
"Mr. Gore, politics and religion are about consensus, not science. No \\
one agreed with Darwin and Galileo but in the end scientific evid- \\
ence proved them correct. It only takes on fact to falsify a theory." \\
(p. 8)
\end{tabular}


Emergent categories of contested science (see Table 2) highlight the use of pseudo-scientific claims and scientific authority appeals in the selected books. Prevalent topics for scientific contestations included: (1) rates of ice melt and sea level rise, (2) threats to polar bear habitats, (3) the role of solar and space phenomena, (4) accuracy of temperature and $\mathrm{CO}_{2}$ records, and (5) the causes and impacts of extreme weather. These challenges to the indicators, impacts, and evidence of climate change are positioned as legitimate and healthy scientific skepticism. However, rather than encourage scientific understanding in the readers, the texts strategically deploy pseudo-scientific arguments that, ironically, simultaneously undermine science while asserting scientific authority.

Table 2: Examples of emergent categories of contested science.

\begin{tabular}{|c|c|}
\hline \multicolumn{2}{|c|}{ Ice Melt/Sea Level Rise } \\
\hline $\begin{array}{l}\text { Sky's Not } \\
\text { Falling }\end{array}$ & $\begin{array}{l}\text { "We only monitor about } 10 \text { percent of the globes' glaciers- half are growing, half are } \\
\text { shrinking." (p. 7) }\end{array}$ \\
\hline $\begin{array}{l}\text { We're Not } \\
\text { Scared }\end{array}$ & $\begin{array}{l}\text { Kids: "Even the IPCC predicts seal levels will only rise about } 20 \text { centimeters over the } \\
\text { next } 100 \text { years. This is about the same rise that occurred last century." (p. 9) }\end{array}$ \\
\hline \multirow[t]{2}{*}{ Real Deal } & $\begin{array}{l}\text { "Most research says that, even if it could occur, melting ice caps and rising sea levels } \\
\text { would take 1,000 to 5,000 years to happen!" (p. 57) }\end{array}$ \\
\hline & $\begin{array}{l}\text { Referring to Holgate (2007): "Sea level has been rising, it is rising more slowly than } \\
\text { has in the past. It is more likely that changes in sea level will follow the recent slowing } \\
\text { trend of a six-inch rise over the last one hundred years or rise even less." (p. 35) }\end{array}$ \\
\hline \multicolumn{2}{|c|}{ Polar Bear Habitats } \\
\hline $\begin{array}{l}\text { Sky's Not } \\
\text { Falling }\end{array}$ & $\begin{array}{l}\text { "Truth be told, we don't know for sure how many polar bears live in places that are toc } \\
\text { cold for humans, so it's hard to tell if total polar bear numbers are falling." (p. 36) }\end{array}$ \\
\hline $\begin{array}{l}\text { We're Not } \\
\text { Scared }\end{array}$ & $\begin{array}{l}\text { Teacher: "More polar bears are killed each year by hunters than climate change. If we } \\
\text { want to help polar bears perhaps we should stop shooting them." (p. 14) }\end{array}$ \\
\hline \multirow[t]{2}{*}{ Real Deal } & $\begin{array}{l}\text { In references to adaptation, "Arctic air temperatures were as high,or higher than at } \\
\text { present in the } 1930 \text { 's and polar bears survived. The even survived the massive melting } \\
\text { of glaciers } 10,000 \text { years ago." (p. } 96 \text { ) }\end{array}$ \\
\hline & $\begin{array}{l}\text { "When you see the heart-wrenching photos of polar bears floating in the ocean on a } \\
\text { chunk of ice... [remember] polar bears can swim over } 60 \text { miles." (p. 99) }\end{array}$ \\
\hline \multicolumn{2}{|c|}{ Solar \& Space Phenomena } \\
\hline \multirow[t]{2}{*}{$\begin{array}{l}\text { Sky's Not } \\
\text { Falling }\end{array}$} & $\begin{array}{l}\text { "The climate on Mars has been warming up too. As a result the polar ice caps on Mars } \\
\text { are shrinking." (p. 23) }\end{array}$ \\
\hline & $\begin{array}{l}\text { "Scientists have found a direct relationship between cosmic rays and the Earth's tem- } \\
\text { perature. Over the last one hundred years they found fewer cosmic rays and fewer } \\
\text { clouds. As a result, the sun's energy has grown more intense." (p. 24) }\end{array}$ \\
\hline Real Deal & $\begin{array}{l}\text { "For years, scientists all over the world believed that more sunspots (on the sun) } \\
\text { brought warmer weather (on the earth)...they found out that solar activity closely } \\
\text { matches what happens to earth's temperature change over the last } 100 \text { years." (p. 22) }\end{array}$ \\
\hline \multicolumn{2}{|c|}{ Temperature \& $\mathrm{CO}_{2}$ Records } \\
\hline \multirow[t]{3}{*}{$\begin{array}{l}\text { Sky's Not } \\
\text { Falling }\end{array}$} & $\begin{array}{l}\text { Referring to Fischer at al. (1999)-“If the temperature changed before the carbon diox- } \\
\text { ide levels rose, carbon dioxide levels are probably not the cause of the temperature } \\
\text { change." (p. 21) }\end{array}$ \\
\hline & "The Earth has warmed about 1 degree Fahrenheit in the last 100 years." (p. 14) \\
\hline & $\begin{array}{l}\text { "From the early } 1900 \text { 's to about } 1940 \text {, a time when your grandparents may have been } \\
\text { alive, temperatures rose even though carbon dioxide emissions were low, In the follow- } \\
\text { ing years, 1940-1975, the temperature increase was slower even though carbon dioxide } \\
\text { emissions were greater- the result of Industrial development." (p. 22) }\end{array}$ \\
\hline \multirow[t]{2}{*}{$\begin{array}{l}\text { We're Not } \\
\text { Scared }\end{array}$} & $\begin{array}{l}\text { Kids holding a graph citing McIntyre\& McItrick (2003) that says: "Medieval warming } \\
\text { period was hotter." (p. 2) }\end{array}$ \\
\hline & $\begin{array}{l}\text { Kids: "It only takes one fact to falsify a theory. For instance, if } \mathrm{CO}_{2} \text { is responsible for } \\
\text { global warming, why is there no hot spot over the tropics?" (p. } 8 \text { ) }\end{array}$ \\
\hline
\end{tabular}




\begin{tabular}{|c|c|}
\hline \multirow[t]{2}{*}{ Real Deal } & $\begin{array}{l}\text { "Ice core records show that higher } \mathrm{CO}_{2} \text { levels increase AFTER temperature rises, NOT } \\
\text { BEFORE! So carbon dioxide can't be the reason that temperature rises." (p. 23) }\end{array}$ \\
\hline & $\begin{array}{l}\text { "Another thing we rarely hear about when it comes to greenhouse gases is that total } \\
\text { man-made GHG contributions only add up to } 0.28 \% \text { of the GHG effect. That's } 0.28 \% \text {, } \\
\text { way less than } 1 \text { percent!" (p. 19) }\end{array}$ \\
\hline \multicolumn{2}{|c|}{ Extreme Weather } \\
\hline $\begin{array}{l}\text { Sky's Not } \\
\text { Falling }\end{array}$ & $\begin{array}{l}\text { "More people live in the path of storms, not that the storms themselves have become } \\
\text { larger or more powerful due to global warming." (p. 33) }\end{array}$ \\
\hline $\begin{array}{l}\text { We're Not } \\
\text { Scared }\end{array}$ & $\begin{array}{l}\text { Kids: "Mr., Gore, even if you are correct, an increase in wind shear will offset } \\
\text { sea temperatures leading to little or no change in hurricane activity." (p. 12) }\end{array}$ \\
\hline
\end{tabular}

What will be the outcomes of global climate change? Rather than challenge the phenomena of climate change, impact skepticism raises questions about the negative outcomes of climate change. This form of skepticism emerged as claims about the quasi-environmental benefits of improved habitats for animals and quality of life for humans. While trend skepticism largely deployed challenges to scientific models and predictions about the future, the examples of impact skepticism focused on varying interpretations of the value of climate change. Rather than deny any impacts, the provided examples (see Table 3) trivialize the impacts of changing climate systems by pointing to sources of negative feedback (e.g. increased plant growth and sea ice growth) and equivocating about the benefits of $\mathrm{CO} 2$ and warmer weather.

Table 3. Examples of impact skepticism focused on positive impacts to humans and habitats.

\begin{tabular}{|ll|}
\hline Children's Book & What will be the outcomes of climate change? \\
\hline Sky's Not Falling & $\begin{array}{l}\text { "Better plant growth makes it easier to grow food. This means food } \\
\text { could become more plentiful and starvation and famine less likely." } \\
\text { (p. 30) } \\
\text { "In Antarctica, at the opposite end of the earth, total sea ice is grow- } \\
\text { ing, and the penguins and seals that live there should like that just } \\
\text { fine (Vaughn 2005). " (p. 9) }\end{array}$ \\
\hline Real Deal & $\begin{array}{l}\text { "During the Medieval Warm Period, not only did the temperature } \\
\text { elevate, but so did the quality of people's lives. There are fewer } \\
\text { storms and fewer floods, and the new sunny climate brought greater } \\
\text { prosperity." (p. 7) }\end{array}$ \\
\hline We're Not Scared & $\begin{array}{l}\text { "As for heat waves, it actually means less people will die from the } \\
\text { cold so it's a good thing. My Nanna says the warmth helps her arth- } \\
\text { ritis." (p. 12) }\end{array}$ \\
\hline
\end{tabular}

What causes climate change? Attribution skepticism raises questions about the causes of climate change. All of the texts engendered uncertainty about the possibility of human impact on a self-regulating planet and posed alternative causes to global warming other than human $\mathrm{CO}_{2}$ emissions. The provided examples (see Table 4) exemplify challenges to claims of human-caused climate change, including making absurd analogies to sources of natural pollution, pointing to alternative causes, and positioning human activities as a small influence in larger, unalterable environmental systems.

What can we do about climate change? Policy skepticism raises questions about how to act in the face of climate change. Controversy over climate change policies 
Table 4. Examples of attribution skepticism focused on the lack of human agency in an ever-changing planet.

\begin{tabular}{|c|c|}
\hline Children's Book & What causes climate change? \\
\hline Sky's Not Falling & $\begin{array}{l}\text { "The warming on earth is like the warming we are seeing on Earth. } \\
\text { If it's happening on Mars, where there are no humans, how can we } \\
\text { be sure that humans cause global warming on earth?" (p. 23) }\end{array}$ \\
\hline We're Not Scared & $\begin{array}{l}\text { "Adding more } \mathrm{CO}_{2} \text { won't do much to the temperature. Mum and } \\
\text { Dad can drive all they want thank you very much." (p. 4) }\end{array}$ \\
\hline \multirow[t]{2}{*}{ Real Deal } & $\begin{array}{l}\text { "Although man's activities are always blamed, these gaseous live- } \\
\text { stock are responsible for } 18 \% \text { of GHG in the atmosphere. They pro- } \\
\text { duce five times more than cars, airplanes, and other forms of trans- } \\
\text { portation put together." (p. 21) }\end{array}$ \\
\hline & $\begin{array}{l}\text { "Could a human change how much heat the sun puts out? Build a } \\
\text { mountain range? Create a dessert? Keep the rain forest rainy? Fill } \\
\text { an Ocean or drain one dry? How about stop an oncoming tornado? } \\
\text { ABSO-TIVELY, POSTIVELY NOT!" (p. 14) }\end{array}$ \\
\hline
\end{tabular}

generally focused on past failures in environmental regulations from an economic trade-off perspective. The provided examples (see Table 5) point to general appeals to the futility of altering $\mathrm{CO}_{2}$ emissions outcomes, as well as more detailed and specific references to historical failures in emissions regulations, ethanol production, carbon offsetting, and other controversial environmental policies (like DDT and clear cutting).

Table 5. Examples of policy skepticism focused on the economic cost-benefit analysis.

\begin{tabular}{|ll|}
\hline Children's Book & What can we do about climate change? \\
\hline Sky's Not Falling & "So began the American love affair with the SUV which often burns \\
& more gas per mile driven than the old station wagon. Again, the end \\
& result was to use more, not less, gas." (p. 44) \\
& "Government financing encourages ethanol production without \\
& considering the full costs or the unintended consequences." (p. 48)
\end{tabular}

\section{Framing climate change policy}

To learn more about the construction of the logic of non-problematicity, researchers examined the skeptical discourse about environmental policies, as well as individual actions, within the selected books. Analysis looked specifically to similarities and differences in how the texts portrayed controversies about climate change policies. These findings illustrate blended and contrasting frames for understanding the nature of policy controversy, including (1) the pairing of narratives about a lack of public accountability and poor governance with frames 
for economic development, and (2) the clear reinforcement of polarizing social conflict frames centered on delegitimizing environmental concern.

Who is responsible for acting? According to Nisbet [2009], public accountability frame position policy making as either in the public interest or serving special interests. Questions of public accountability emphasize issues over the proper use of science and experts in decision-making. Economic development frames, in contrast, are defined by the focus on the investments, market benefits or risks, and issues of global competitiveness. In the Sky's Not Falling and the Real Deal, analyses revealed a mutually reinforcing interaction between the public accountability and economic development frames which inform a specific value criteria for making environmental decision-making and suggest the appropriate role of governing agencies in these matters.

In the Sky's Not Falling, the author combines past examples of bad governance resulting from environmental policy making with free-market viewpoints. In one example, the authors encourage students to become enviroprenuers rather than environmentalists by explaining, "Enviroprenuers don't force their beliefs on others... They don't think government or some other person should fix everything for them... They don't regulate - they innovate" (pg. 76). The final chapter of the book includes critical thinking exercises leading readers through the logical progression of understanding how the market works, role-playing a store owner, and then weighing market trade-offs of spending money on global warming solutions. This enviropreneur framing strategy mimics the discourse of ecological modernization through appeals to neo-liberal economic and social progress.

Economic resistance to climate change policy making is coupled with a highly contested history of poor environmental governance found across the books. In the Real Deal, the author made appeals to free market ideology in the face of a detailed list of past ineffective regulations and failures in environmental governance. Most notably, environmental policymaking is portrayed as a "push to end industry" and a "fight to end our personal freedoms" [Schmidt, 2008, p. 79]. In terms of economic development, free-market innovations and personal free choice are prominent values that trump environmental concerns.

Whom can we trust? In We're Not Scared, the author made very few policy skepticism arguments because the narrative focused on children actively engaged in pseudo-scientific argumentation about global warming trends, causes, and impacts with $\mathrm{Al} \mathrm{Gore.} \mathrm{While} \mathrm{the} \mathrm{narrative} \mathrm{as} \mathrm{a} \mathrm{whole} \mathrm{raises} \mathrm{the} \mathrm{question} \mathrm{of} \mathrm{how} \mathrm{to} \mathrm{(or}$ whether to) teach climate science in schools, the positioning of $\mathrm{Al}$ Gore as the antagonist in the story is illustrative of social conflict framing. The behaviour modelled by the story characters suggests that children should challenge science teachers with scientific evidence and counterclaims from personal experience. Most shockingly, in the final page of the book, the classroom teacher is pointing a gun at $\mathrm{Al}$ Gore as he runs away in a herd of polar bears.

According to Nisbet [2009], social conflict frames position controversy as a battle between personalities and groups. Social conflict framing is easily identified in the Real Deal, where global warming advocates were derogatorily named as trendy, alarmists, and radical environmentalists, despite the author's inclusion of a sticks and stones section explaining downfalls of name-calling (like skeptic, denier, flat 
Earther, and immoral) [Schmidt, 2008, p. 59]. The book further invoked the do-as-I say not as-I-do motto to highlight the contradictions of global air travel, limousines, and electricity used by popular environmentalist celebrities. As the author of the Real Deal explains, "Radical environmental activist groups are not to be mistaken with all environmental groups; some environmentalist groups care about the earth, but also care about the well-being of people, first" [Schmidt, 2008, p. 35].

The social conflict frame clearly pits environmentalism against ecological modernization to the extreme point of abandoning all expected American conveniences. Bolstering the value of economic development to social progress, readers are asked to imagine the daily toils of life with no cars, electricity, or indoor bathrooms. One book quintessentially reminds children of developing countries where people live without electricity (i.e. "when the sun goes down, their day is over" [Schmidt, 2008, p. 37] and where people are unable to keep medicine from spoiling and use dung for campfires that cause respiratory problems). Often, social conflict frames did not overtly align with conservative politics or the Republican Party, but employed a derogatory approach to environmental ethics that position consumption as a privileged but necessary lifestyle.

The texts further encouraged readers to understand environmental concern and environmental policy making as problems. In the Real Deal, multiple pages were allocated to indicting the use of fear and exaggeration about catastrophic outcomes to gain adherence for the theory of global warming. Environmentalists were labeled as fatalists for spreading repetitive doomsday messages through "movies, commercials, talk shows, schools, books, billboards, documentaries, websites, comic books, magazines" [Schmidt, 2008, p. 58]. An entire chapter was devoted to the indictment of the "environmental machine" for actions like preventing drilling in Arctic National Wildlife Refuge (ANWR), banning DDT leading to malaria deaths, and focusing on doing humane animal research rather than advancing research to improve human health [Schmidt, 2008, p. 74-84].

In summary, the framing of climate change controversies as an issue of poor environmental governance jeopardizing U.S. economic development reinforces the logic of non-problematicity. Unabashedly loaded social conflict frames, found across all three texts, emphasized the dualism between skeptical and convinced logics that unfortunately characterize contemporary U.S. policy debates. Blended frames, of economic development and social conflict raise concerns about lifestyle changes due to environmental governance and engender distrust about different sources of environmental concern.

\section{Uncertainty management appeals}

The Norton, Sias and Brown [2011] typology allowed researchers to explore the construction of a logic of non-problematicity as an individual cognitive construction by identifying strategies for managing uncertainty about climate change that might reinforce pre-existing risk aversions and mental models of the world. Analyses revealed how the texts activate a complicated notion of individual agency that challenges scientific consensus, encourages imagined information seeking, and appeals to variety of worldviews. 
As expected, the denial strategy was reinforced by the skeptical arguments in the books, including overt claims that climate change is not happening or will positively affect our lives. For readers still negotiating the meaning behind the public climate change controversies, some alternatives to simply denying the consensus conclusion were presented. Other strategies for managing the uncertainty about climate change included: (a) seeking (or imagined seeking) more information, (b) viewing the problem as tolerable, (c) associating uncertainty with other more certain causes, or (d) accepting our inability to know truth or act.

Examples of the seeking more information strategy to reduce uncertainty were easy to identify in the Real Deal where each section is repeatedly accompanied by the image of magnifying glasses prompting readers to check-it out. The author proposed, "If you're like me, you've probably got some really cool people in your life. People you can trust to tell you the truth and give you great information on all kinds of stuff. But, where are we getting this information on global warming from?" [Schmidt, 2008, p. 64]. The chapter continues to indict the media, Hollywood celebrities, schools, and politicians. Independent information seeking (not scientific consensus) is understood as the key to deciphering the truth from the hype. In the Sky's Not Falling, students are provided with a set of activities to "exercise your mind so you can make your thinking skills better" [Fretwell, 2007, p. 77]. One example (embedded within economic development frames) includes a carbon footprint activity that justifies the US carbon footprint as a sign of productivity. This is followed by other activities that demonstrate the cost of zero-pollution.

Indeed, the books themselves often activate a sense of imagined information seeking strategy as in this example: "Sadly, too many of us won't do the work to find out the other side of this issue for ourselves (of course, not you, because you're reading this book)." [Schmidt, 2008, p. 58]. The imagined information seeking strategy complements appeals to independent decision-making despite scientific consensus. For example, in the Real Deal, readers are assured, "Luckily, there are many respected scientists who are trying to get the word out and tell us more comforting truth; that all these terrible, scary events are highly unlikely to happen" [Schmidt, 2008, p. 54].

Examples of the tolerance strategy were easily identified in statements like, "Geologists have known the climate has changed for a long time. For climate, change is the only certainty. We need to treat it like any other natural hazard and deal with it as it comes" (p. 8). The trivialization of climate change as minor, gradual, normal, and thus tolerable is closely tied to impact skepticism arguments. In this way, the tolerance strategy often accompanies assumptions that changes will happen slowly or will be positive. The assimilation strategy, discussed below, often similarly accompanies trend skepticism (i.e. climate change as a natural occurrence) to create alternate causality arguments.

By definition, the assimiliation strategy asks readers to assimilate uncertainty into other less uncertain categories. A prominent recurring example relies on social conflict frames, discussed above, by suggesting that readers understand the global warming debate as the result of an environmental agenda rather than a true environmental problem. This fact is overtly addressed in the Real Deal when authors respond to evidence of global warming in the form of charts and graphs: "This fear technique works the same way when we ride a really gnarly roller coaster, 
or watch a freakishly spooky zombie movie. Even though deep down you know you're not in any real danger, your mind gets carried away" [Schmidt, 2008, p. 52].

The tolerance and assimilation strategies tend to undermine the reality and urgency of climate change; whereas the acceptance strategy suggests one resign from managing uncertainty all together. The acceptance strategy accompanies statements that encouraged students to disassociate from the problem by accepting the inevitable uncertainty of science (e.g., "The truth is that no one, not even the best scientists, knows why some places are becoming warmer and others cooler" [Fretwell, 2007, p. 9] ). This strategy also appealed to the limited capacity for humans to change earth systems [e.g.," Think about how powerless we are... Climate change is one of the natural miraculous things that make planet Earth such an amazing creation" Fretwell, 2007, p. 14-16].

In sum, the rhetorical analysis of uncertainty management appeals helped to clarify the authors' cognitive structuring of the logic of non-problematicity. In response to the uncertainty of climate change, readers are encouraged to seek more information, view the problem as tolerable, associate with other causes, and accept our inability to know truth or act. Rather than simply deny the problems, these strategies appeal to varying forms of climate change skepticism, worldviews, mental models of change, and existing risk aversions. By engendering scientific and social uncertainty, and then managing for that uncertainty, these reviewed texts arguably embolden individuals' disassociation from the causes, impacts, and solutions to climate change that is emblematic of the logic of non-problematicity.

The purpose of this research was to explore some ways students, teachers, and parents might encounter climate change skepticism in pseudo-educational media. Specifically, the research asked, how are climate change denial discourses reproduced in children's books? The results highlighted a varied composition of skeptical arguments, blended frames for understanding environmental policy controversies, and numerous tips for managing uncertainty about climate change. After a summary of the findings, below, we discuss the brokering power of appeals to independent decision-making over scientific consensus, as well as dominant narratives of ecological modernization that cast doubt about on the value of environmental concern.

The various forms of skepticism found in these children's books were conceptually consistent with other research in climate change denial rhetoric. Contradictory skeptical claims were commonly deployed together. Identified areas of contested science knowledge illustrated a common contradiction in climate change denial media of undermining science while asserting scientific authority [Doyle, 2011]. Skepticism about climate change supports a logic of non-problematicity by: (a) delegitimizing scientific consensus and deploying tropes of uncertainty to engender skepticism about climate change trends, (b) drawing on misconceptions about the self-regulating and ever-changing nature of earth systems to engender skepticism about the severity of impacts, and (c) qualifying the limits to human agency and highlighting the economic trade-offs to solving environmental problems to engender skepticism about the causes of climate change (attribution), as well as what we can do about it (policy). 
Readers were provided with a set of familiar frames for scientific controversies, as well as uncertainty management appeals, which encourage policy inaction. Blended, complementary frames for understanding the nature of climate change policy controversies included: (a) the pairing of narratives about the lack of public accountability and poor governance with frames for economic development, and (b) the clear reinforcement of polarizing social conflict frames centered on delegitimizing environmental actors and concerns. Dominant narratives of ecological modernization reinforced questions about who pays the costs of policy actions, whether we should have decentralized or centralized systems, and whether the costs of acting outweigh the benefits [Bäckstrand and Lövbrand, 2007]. While the social conflict frame was positioned at all levels of society (news media, politics, movies, science, and now even your school), economic development frames located the problem with climate change in the politics of environmental governance. A number of uncertainty management strategies further disassociated readers from the causes, impacts, and solutions to climate change.

Discussion

This study was limited to three examples of climate change denial books for children and we can only speculate about the broader dissemination and widespread impact of these skeptical books for parents, teachers, and children. Little is known about the books' distribution and readership. Future research focused on behavioural and attitudinal change arising from exposure to pseudo-educational materials would be valuable. Additional, comparative research along a range of skeptical media (e.g. dismissive, hesitant, and adherent) could inform a better understanding of the logic of non-problematicity about climate change in terms of conceptual, behavioural, and attitudinal change [Kahan, Jenkins-Smith and Braman, 2011; Meehan, 2012]. To more thoroughly understand the large scale impacts of the widespread climate change denial campaigns aimed at parents, teachers, and children, future research might also address group membership, rates of readership, and the dissemination strategies for various forms of pseudo-educational media produced by organizations like the Heartland Institute and American Legislative Exchange Council (ALEC).

Questions of how to support learners in seeking accurate information about climate change or identifying misinformation are increasingly relevant. This research aimed to contribute a better understanding of the rhetorical strategies and motivational appeals that engender apathy and inaction in the public sphere. The sampled texts provide examples of how contestations over climate change are rhetorically shaped through contradictory forms of skepticism and polarizing anti-environmentalist frames. The material world matters, but a myriad of rhetorical practices and ideologies serve as broker issues in resolving differences about how we understand the problem with climate change. The results suggest that the trial of strength of skeptical discourse coalitions extends beyond tropes of uncertainty and risk management [Besel, 2011; Latour, 1997]. For this reason, scholarship in environmental communication and science education will benefit from conceptualizing the controversies about climate change as an entangled set of cultural narratives, rather than primarily symptomatic of a logic schism driven by manufactured scientific controversy [Hoffman, 2011].

The existence of skeptical books for children indeed raises questions about the constitutive force of such media to reinforce the logic of non-problematicity about 
climate change. Arguably, appeals to dominant narratives of ecological modernization and independent decision-making are overlooked

brokering-devices used by climate change deniers aimed at reinforcing apathy and inaction in the public sphere. The skeptical appeals to independent decision-making often compliment narratives of ecological modernization by placing the criteria for decision-making in the context of economic development. Narratives of ecological modernization focus environmental decision-making on seemingly rational policy analysis by asking questions about who pays the costs, whether we should have decentralized or centralized systems, and whether the costs of acting outweigh the benefits. Unfortunately, the problematization of environmental concern simultaneously rests on the anthropocentric cost-benefit-risk analysis that emblematically pits environment against economic prosperity.

As Bäckstrand and Lövbrand [2007] explained, critical discourse analyses can help to identify power relationships in environmental policy making that result from dominant narratives of ecological modernization. In this study, narratives of ecological modernization weighed individual lifestyle preferences (from toys to toilets) against a history of failed environmental regulations. Given the unrelenting slander of past environmental policies and climate change activism, the invention of the term enviroprenuership seems like an utterly disingenuous effort to construct an environmental ethic based on the assumption that a deregulated free market will solve environmental problems for us.

But perhaps, appeals to independent decision-making (over clearly established scientific consensus) newly emerged here as a pedagogical dilemma for educators, environmental advocates, and communication experts interested in advancing understanding and action in the face of rapid climate change. Indeed, one of the most striking elements across all of the books was the way in which authors' encouraged readers to question the intentions of scientists and environmentalists. Argumentative engagements in selected areas of contested science knowledge, like polar bears habitats and solar flares, illustrate the contradiction of undermining science while asserting scientific authority.

Whether one chooses to seek more information (or just imagine they have), pseudo-scientific claims focused on popularized areas of contested science do more than just engender misinformation and scientific uncertainty; they activate a need for independent decision-making. One text even offered suggestions on how to "politely ask your teacher to turn that global warming movie off and teach you something that matters" [Schmidt, 2008, p. 69]. Clearly, manufactured controversy about climate change easily translates into manufactured controversy about climate change education. Not surprisingly, similar appeals to independent decisionmaking can be seen in the contemporary legislative discourse associated with the Teach the Controversy movement, which deny scientific consensus on global warming and pair climate change with other controversial topics like evolution [National Center for Science Education, 2013; Colston and Vadjunec, 2015].

As Cooper [2011] pointed out in her call for increased media literacy, the success of climate change denial campaigns rests on appeals to open scientific debate and empower individuals as discursive agents in the controversy. Appeals to independent decision-making engage readers as agents in knowledge construction, 
rather than positioning them as non-experts in need of a science lesson. However, can and should children, parents, and science teachers be engaged in deciding the truth about climate change for themselves? As a brokering device across audiences, appeals to independent decision-making draw on the highly privileged democratic ideal of pluralism to answer this question. For example, climate change skeptics' call for independent decision-making neatly resonates within polarized narratives of conspiracy that suggest scientists, politicians, and teachers are not trustworthy.

Rather than replicating such polarizing frames or overemphasizing scientific consensus, science communication scholars must continue to investigate new educational and rhetorical tools for responding to climate change skeptics who teach climate literacy. Beyond framing [Cox, 2013], environmental communication scholars should continue to trace the rhetorical strategies and persuasive devices that sustain not just doubt about climate change science, but the logic of non-problematicity and inaction across heterogeneous groups. This study reveals the clear and present danger of organized climate change denial campaigns in the reverberation of rhetorical strategies that provide a sense of agency through imagined information seeking and reconfigure the core values of environmental citizenship along frames of economic development.

\section{References}

Al Sonja Schmidt (2008). Al Sonja Schmidt on Fox Business. [Video]. URL: https : //www . youtube . com/watch?v=WdqQH9JWfrE.

Antilla, L. (2005). 'Climate of scepticism: US newspaper coverage of the science of climate change'. Global Environmental Change 15 (4), pp. 338-352. https://doi.org/10.1016/j.gloenvcha.2005.08.003.

Bäckstrand, K. and Lövbrand, E. (2007). 'Climate governance beyond 2012: competing discourses of green governmentality, ecological modernization and civic environmentalism'. In: The social construction of climate change. Ed. by M. Pettenger. London, U.K.: Ashgate Publishers, pp. 123-147.

Benford, R. D. and Snow, D. A. (2000). 'Framing processes and social movements: an overview and assessment'. Annual Review of Sociology 26 (1), pp. 611-639. https://doi.org/10.1146/annurev.soc.26.1.611.

Bennett, J. O. and Collier-Morales, R. (2011). The wizard who saved the world. Boulder, CO, U.S.A.: Big kid Science.

Besel, R. D. (2011). 'Opening the "black box" of climate change science: actor-network theory and rhetorical practice in scientific controversies'. Southern Communication Journal 76 (2), pp. 120-136. https://doi.org/10.1080/10417941003642403.

Boykoff, M. T. and Boykoff, J. M. (2004). 'Balance as bias: global warming and the US prestige press'. Global Environmental Change 14 (2), pp. 125-136. https://doi.org/10.1016/j.gloenvcha.2003.10.001.

Bozdogan, A. E. (2011). 'The effects of instruction with visual materials on the development of preservice elementary teachers' knowledge and attitude towards global warming'. Turkish Online Journal of Educational Technology 10 (2), pp. 218-233.

Buttel, F. H. (1996). 'Environmental and resource sociology: theoretical issues and opportunities for synthesis'. Rural Sociology 61 (1), pp. 56-75. URL: http://core.ecu.edu/soci/juskaa/buttel.htm.

- (2000). 'Ecological modernization as social theory'. Geoforum 31 (1), pp. 57-65. https://doi.org/10.1016/s0016-7185(99)00044-5. 
Carvalho, A. (2010). 'Media(ted) discourses and climate change: a focus on political subjectivity and (dis)engagement'. Wiley Interdisciplinary Reviews: Climate Change 1 (2), pp. 172-179. https://doi.org/10.1002/wcc. 13.

Ceccarelli, L. (2011a). Shaping science with rhetoric. Chicago, IL, U.S.A.: University of Chicago Press.

Ceccarelli, L. (2011b). 'Manufactured scientific controversy: science, rhetoric and public debate'. Rhetoric E Public Affairs 14 (2), pp. 195-228. https://doi.org/10.1353/rap.2010.0222.

Cherry, L. and Braasch, G. (2008). How we know what we know about our changing climate. Nevada City, CA, U.S.A.: Dawn Publications.

Colston, N. M. and Ivey, T. A. (2015). '(Un)Doing the next generation science standards: climate change education actor-networks in Oklahoma'. Journal of Education Policy 30 (6), pp. 773-795. https://doi.org/10.1080/02680939.2015.1011711.

Colston, N. M. and Vadjunec, J. M. (2015). 'A critical political ecology of consensus: on "teaching both sides" of climate change controversies'. Geoforum 65, pp. 255-265. https://doi.org/10.1016/j .geoforum. 2015.08.006.

Cook, J. (2009). A scientific guide to the Skeptics Handbook: the evidence that humans are causing climate change. URL: http://www. skepticalscience.com/docs/Scienti ficGuideSkepticsA5.pdf.

Cook, J. and Lewandowsky, S. (2011). The debunking handbook. St. Lucia, QLD, Australia: University of Queensland. URL: http://sks. to/debunk.

Cooper, C. B. (2011). 'Media literacy as a key strategy toward improving public acceptance of climate change science'. BioScience 61 (3), pp. 231-237. https://doi.org/10.1525/bio.2011.61.3.8.

Cox, R. (2013). Environmental communication and the public sphere. 3rd ed. Thousand Oaks, CA, U.S.A.: Sage Publications.

Creswell, J. W. and Plano Clark, V. L. (2007). Designing and conducting mixed methods research. Thousand Oaks, CA, U.S.A.: Sage Publications.

Doyle, J. (2011). Mediating climate change. Farnham, U.K.: Ashgate.

Dugan, A. (2015). 'Conservative republicans alone on global warming's timing'. Gallup. URL: http://www.gallup.com/poll/182807/conservative-republican s-alone-global-warming-timing. aspx.

Dunlap, R. E. and McCright, A. M. (2010). 'Climate change denial: sources, actors and strategies'. In: Routledge handbook of climate change and society. Ed. by C. Lever-Tracy. Abingdon, U.K.: Routledge, pp. 240-259.

Dunlap, R. E. and McCright, A. M. (2011). 'Organized climate change denial'. In: The Oxford handbook of climate change and society. Ed. by J. S. Dryzek, R. B. Norgaard and D. Schlosberg. Oxford, U.K.: Oxford University Press, pp. 145-160. https://doi.org/10.1093/oxfordhb/9780199566600.003.0010.

Farrell, J. (2015). 'Politics: echo chambers and false certainty'. Nature Climate Change 5 (8), pp. 719-720. https://doi.org/10.1038/nclimate2732.

Fretwell, H. (2007). The sky's not falling! Why it's OK to chill about global warming. New York, NY, U.S.A.: Kid Ahead Books.

- (2009). 'Environmental education: the science of fear'. PERC Reports. URL: https://www . perc.org/2009/09/24/environmental-education-the-sci ence-of-fear/.

Freudenburg, W. R. (2000). Social constructions and social constrictions: toward analyzing the social construction of 'the naturalized' as well as 'the natural'. London, U.K.: Sage Publications. 
Glaser, B. and Strauss, A. L. (1967). The discovery of grounded theory: strategies for qualitative research. Chicago, IL, U.S.A.: Aldine.

Hansen, A. and Machin, D. (2008). 'Visually branding the environment: climate change as a marketing opportunity'. Discourse Studies 10 (6), pp. 777-794. https://doi.org/10.1177/1461445608098200.

Hendrickx, M. (2008a). We're not scared anymore Mr. Gore. A climate change story for little skeptics. ISBN:978-0-9805943-1-7. Australia: Little Skeptics Press.

Hendrickx, M. (2008b). We are not scared anymore Al Gore. [Video]. URL: http://www . youtube. com/watch?v=DW9_RkHlz2Q.

Hoffman, A. J. (2011). 'Talking past each other? Cultural framing of skeptical and convinced logics in the climate change debate'. Organization $\mathcal{E}$ Environment 24 (1), pp. 3-33. https://doi.org/10.2139/ssrn.1768882.

Johnson, R. (2011). Climate change education in K-12: teacher preparation, understanding, needs and concerns. Slingerlands, NY, U.S.A.

URL: http://sites . nationalacademies .org/cs/groups/dbassesite/documen ts/webpage/dbasse_072566.pdf.

Kahan, D. M., Jenkins-Smith, H. and Braman, D. (2011). 'Cultural cognition of scientific consensus'. Journal of Risk Research 14 (2), pp. 147-174. https://doi.org/10.1080/13669877.2010.511246.

Knain, E. (2015). Scientific literacy for participation: a systemic functional approach to analysis of school science discourses. Rotterdam, The Netherlands: SensePublishers. https://doi.org/10.1007/978-94-6209-896-1.

Lambert, J. L., Lindgren, J. and Bleicher, R. (2012). 'Assessing elementary science methods students' understanding about global climate change'. International Journal of Science Education 34 (8), pp. 1167-1187. https://doi.org/10.1080/09500693.2011.633938.

Latour, B. (1997). 'The trouble with actor-network theory'. Soziale Welt 47, pp. 369-381.

Lemke, J. (1993). 'Multiplying meaning: visual and verbal semiotics in scientific text'. In: Reading science: critical and functional perspectives on discourse of science. Ed. by J. R. Martin and R. Veel. London, U.K.: Routledge, pp. 87-113.

McBean, G. A. and Hengeveld, H. G. (2000). 'Communicating the science of climate change: a mutual challenge for scientists and educators'. Canadian Journal of Environmental Education (CJEE) 5 (1), pp. 9-25.

URL: https://cjee.lakeheadu.ca/article/view/298.

McCaffrey, M. S. and Buhr, S. M. (2008). 'Clarifying climate confusion: addressing systemic holes, cognitive gaps and misconceptions through climate literacy'. Physical Geography 29 (6), pp. 512-528.

https://doi.org/10.2747/0272-3646.29.6.512.

McCright, A. M. and Dunlap, R. E. (2000). 'Challenging global warming as a social problem: an analysis of the conservative movement's counter-claims'. Social Problems 47 (4), pp. 499-522. https: //doi .org/10.2307/3097132.

Meehan, C. R. (2012). 'Global warming in schools: an inquiry about the competing conceptions of high school social studies and science curricula and teachers'. Dissertation submitted in partial fulfillment of the requirements for the degree of Doctor of Philosophy. Madison, WI, U.S.A.: University of Wisconsin. URL: http://depot.library.wisc .edu/repository/fedora/1711.dl: OQUU3BY 4BGAV08B/datastreams/REF/content. 
Meehan, C. R., Levy, B. L. M. and Collet-Gildard, L. (2018). 'Global climate change in U.S. high school curricula: portrayals of the causes, consequences, and potential responses'. Science Education 102 (3), pp. 498-528.

https://doi.org/10.1002/sce.21338.

Monroe, M. C., Plate, R. R., Oxarart, A., Bowers, A. and Chaves, W. A. (2017). 'Identifying effective climate change education strategies: a systematic review of the research'. Environmental Education Research, pp. 1-22. https://doi.org/10.1080/13504622.2017.1360842.

Nathan, S. W. (1951). Chicken little. New York, NY, U.S.A.: Golden Books/Random House.

National Center for Science Education (2012). Climate change denial is affecting education.

URL: http://ncse.com/climate/denial/denial-affecting-education.

- (2013). NGSS adoption update.

URL: http://ncse.com/news/2013/07/ngss-adoption-update-0014887 (visited on 24th February 2014).

Nisbet, M. C. (2009). 'Communicating climate change: why frames matter for public engagement'. Environment: Science and Policy for Sustainable Development 51 (2), pp. 12-23. https://doi.org/10.3200/ENVT.51.2.12-23.

Norton, T., Sias, P. and Brown, S. (2011). 'Experiencing and managing uncertainty about climate change'. Journal of Applied Communication Research 39 (3), pp. 290-309. https://doi.org/10.1080/00909882.2011.585397.

Nova, J. (2009). The skeptic's handbook. URL: http://joannenova. com.au/global-warming-2/.

Okimoto, J. D. and Trammell, J. (2013). Winston of Churchill: one bear's battle against global warming. Seattle, WA, U.S.A.: Sasquatch Books.

Oreskes, N. and Conway, E. (2010). Merchants of doubt: how a handful of scientists obscured the truth on issues from tobacco smoke to global warming. New York, NY, U.S.A.: Bloomsbury Press.

Peterson, T. C., Connolley, W. M. and Fleck, J. (2008). 'The myth of the 1970s global cooling scientific consensus'. Bulletin of the American Meteorological Society 89 (9), pp. 1325-1338. https://doi.org/10.1175/2008bams2370.1.

Rahmstorf, S. (2004). 'The climate sceptics'. In: Weather catastrophes and climate change: is there still hope for us? Ed. by Münchner-RE. München, Germany: PG Verlag, pp. 76-83. URL: http://www.pik-potsdam.de/ stefan/Publications/0 ther/rahmstorf_climate_sceptics_2004.pdf.

Reardon, S. (2011). 'Climate change sparks battles in classroom'. Science 333 (6043), pp. 688-689. https://doi.org/10.1126/science.333.6043.688.

Reitan, R. and Gibson, S. (2012). 'Climate change or social change? Environmental and leftist praxis and participatory action research'. Globalizations 9 (3), pp. 395-410. https://doi.org/10.1080/14747731.2012.680735.

Robinson, M. (2008). America debates global warming: crisis or myth? New York, NY, U.S.A.: Rosen Central.

Rousell, D., Cutter-Mackenzie, A. and Foster, J. (2017). 'Children of an earth to come: speculative fiction, geophilosophy and climate change education research'. Educational Studies 53 (6), pp. 654-669. https://doi.org/10.1080/00131946.2017.1369086.

Schmidt, A. S. (2008). Deb and seby's real deal on global warming. Bloomington, IN, U.S.A.: Authorhouse. 
Shackley, S. and Wynne, B. (1996). 'Representing uncertainty in global climate change science and policy: boundary-ordering devices and authority'. Science, Technology, \& Human Values 21 (3), pp. 275-302. https://doi.org/10.1177/016224399602100302.

Sharman, A. and Howarth, C. (2017). 'Climate stories: why do climate scientists and sceptical voices participate in the climate debate?' Public Understanding of Science 26 (7), pp. 826-842. https://doi.org/10.1177/0963662516632453.

Truong-White, H. and McLean, L. (2015). 'Digital storytelling for transformative global citizenship education'. Canadian Journal of Education 38 (2), pp. 1-28. URL: http://journals.sfu.ca/cje/index.php/cje-rce/article/view/1756.

Wainwright, J. and Mann, G. (2013). 'Climate leviathan'. Antipode 45 (1), pp. 1-22. https://doi.org/10.1111/j.1467-8330.2012.01018.x.

Weart, S. (2011). 'Global warming: how skepticism became denial'. Bulletin of the Atomic Scientists 67 (1), pp. 41-50. https://doi.org/10.1177/0096340210392966.

Wodak, R. and Meyer, M., eds. (2015). Methods of critical discourse studies. U.K.: Sage.

Worth, K. (28th March 2017). 'Climate change skeptic groups seeks to influence 200,000 teachers'. Frontline. URL: https://www. pbs.org/wgbh/frontline/artic le/climate-change-skeptic-group-seeks-to-influence-200000-teachers/. Youth climate strike (15th March 2019). CBS Interactive.

URL: https://www . cbsnews. com/news/youth-climate-strike-students-skip -class-demand-tough-action-on-climate-change/.

Authors

Nicole Colston is Assistant Research Professor in the Center for Research in STEM Teaching and Learning at Oklahoma State University. Her interdisciplinary research agenda is focused on the intersections of science communication and environmental education. E-mail: nicole.colston@okstate.edu.

Julie Thomas is a Research Professor at the University of Nebraska-Lincoln. Her research interests include indoor and outdoor environmental education initiatives to improve science and mathematics learning for PreK-12 classroom teachers and children. E-mail: julie.thomas@unl.edu.

\section{How to cite}

Colston, N. M. and Thomas, J. (2019). 'Climate change skeptics teach climate literacy? A critical discourse analysis of children's books'. JCOM 18 (04), A02. https://doi.org/10.22323/2.18040202. 